\title{
Extraction of sweet wormwood (Artemisia annua L.) by supercritical carbon dioxide
}

\author{
Senka Vidović ${ }^{1}$, Siniša Simić ${ }^{1}$, Aleksandra Gavarić ${ }^{1}$, Milica Aćımovićc ${ }^{2}$, AND Jelena \\ VLADIĆ ${ }^{1^{*}}$ \\ ${ }^{1}$ University of Novi Sad, Faculty of Technology, Bulevar cara Lazara 1, 21000 Novi Sad, Serbia \\ ${ }^{2}$ Institute of Field and Vegetable Crops, Maksima Gorkog 30, 21000 Novi Sad, Serbia \\ *Corresponding author: vladicjelena@gmail.com
}

Received: September 9, 2020

Accepted: November 20, 2020

Published on-line: December 20, 2020

Published: December 25, 2020

\begin{abstract}
In this study, supercritical carbon dioxide was applied for the extraction of Artemisia annua L. Moreover, the impact of different parameters of supercritical extraction on total yield was investigated and the obtained yields were compared to the ones obtained by conventional procedures, hydrodistillation and Soxhlet extraction. Supercritical fluid extraction at $40{ }^{\circ} \mathrm{C}$ and different pressures $(100,200$, and 300 bar) resulted in extraction yields that were in the 2.23-5.18 \% range, while the yields at $60{ }^{\circ} \mathrm{C}$ and the same pressures were in the range $2.43-3.35 \%$. The yields obtained by the Soxhlet extraction and hydrodistillation were $\mathbf{1 0 . 2 8} \%$ and $\mathbf{0 . 1 0} \%$, respectively. Although supercritical fluid extraction is inferior to Soxhlet extraction in terms of the recovery of lipophilic components of A. annua, the Soxhlet extraction is not the method of choice for obtaining sweet wormwood extracts due to its numerous disadvantages that include the use of toxic solvents, extended extraction time, health safety of the product, the need for further processing, the impossibility of adjusting the selectivity and thus the composition of the product.
\end{abstract}

Key words: Artemisia annua L., supercritical extraction, Soxhlet extraction, hydrodistillation

\section{INTRODUCTION}

The genus Artemisia belongs to the large family of Asteraceae, encompassing more than 300 species. Artemisia annua L., commonly known as sweet wormwood (SW), indigenous to Southeast Asia, is an annual herb, which has become cultivated as a medicinal plant in many parts of Asia, Africa, Europe, America, and Australia (Wright, 2005). Artemisia spp. are rich in secondary metabolites, which may elucidate their use as bittering agents, perfumes, culinary spices, and hallucinogens (Ferreira et al., 1997; Watson et al., 2002). Apart from A. annua, only two other species, $A$. apiaceae and A. lancea, have been shown to possess artemisinin (Tan et al., 1998), which is widely used as a single compound anti-malarial drug in combination therapies and approved by The United States Food and Drug Administration (Graziose et al., 2010). In addition, artemisinin, with the help of the endoperoxide group, shows promising anticancer activities when tested in vitro and in vivo (Efferth et al., 2001; Moore et al., 1995; Singh and Lai, 2001). Artemisinin is a sesquiterpene lactone and its concentration in $A$. annua varies from 0.01 to over $2.0 \%$ in some selected cultivars. Therefore, a great deal of work has been focused on the cultivation and optimization of high artemisinin-yielding cultivars of $A$. annua (Ferreira et al., 1997; Laughlin et al., 2002).
Some studies have reported insecticidal effects of $A$. annua extract including growth retardation, as well as antifeedant and larvicidal effects (Haghighian et al., 2008; Hasheminia et al., 2011; Shekari et al., 2008). Khosravi et al. (2010) showed strong antifeedant activity of this plant extract against Glyphodes pyloalis larvae and significant effects on nutritional indices and biochemical parameters. In addition to antimalarial activity, extracts obtained from $A$. annua have been used to induce hair growth, to promote longevity, as a food additive, as an antiinflammatory, as well as a treatment for numerous external ails including hemorrhoids, lice, and ulcers (Hsu, 2006).

Therefore, $A$. annua represents a raw material with great pharmacological potential. Apart from its most investigated compound artemisinin, numerous other classes of phytochemicals have also been isolated from $A$. annua including monoterpenes, sesquiterpenes, triterpenoids, steroids, various lipids, flavonoids, coumarins, and other polyphenolics (Bhakuni et al., 2002). Hence, further investigation of the potential of $A$. annua is necessary.

A very important aspect that dictates the application, market competitiveness, and acceptance of products on the basis of A. annua is the form of the product, that is, their production procedure. Well-established conventional methods of extrac- 
tion of $A$. annua include the application of non-polar organic solvents under reflux conditions (Lapkin et al., 2006). Considering the unfavorable ecological and health aspects of these production procedures, and the rising aspiration of the industry to implement green technologies and meet stringent environmental regulations, processes that offer an environmentally safe production procedure and quality products are highly required.

One green modern technology that was established as a method of choice for obtaining lipophilic extracts is the supercritical carbon dioxide extraction $\left(\mathrm{SC}-\mathrm{CO}_{2}\right)$. Due to favorable conditions for achieving supercritical conditions, as well as the low price, availability and safety of application of $\mathrm{CO}_{2}$, the possibility of selective extraction and fractioning, $\mathrm{SC}-\mathrm{CO}_{2}$ is more present in the industry. The additional advantage is the attainment of extract free from the presence of solvents, hence, purification of extracts is not necessary. Considering the quality of the product, the safety of the process, and market competitiveness, the initial purchase of equipment represents a worthy investment (Nađalin et al., 2014; Sahena et al., 2009; Vladić et al., 2016). In this study, the aim was to compare the efficiency of $\mathrm{SC}-\mathrm{CO}_{2}$ and conventional extraction methods of A. annua in terms of extraction yield and to determine optimal pressure and temperature for obtaining the highest yield. The impact of different densities of SC-CO $\mathrm{C}_{2}$ on extraction yield was investigated.

\section{MATERIALS AND METHODS}

\subsection{Plant material}

The aerial parts of $A$. annua L. grown on the experimental field in Bački Petrovac, within the Institute for Organic Production and Biodiversity, Novi Sad were used in this study. The dried A. annua was grounded in a domestic blender and the mean particle size $(0.35 \mathrm{~mm})$ of herbal material was determined using vibration sieve sets (CISA, Cedaceria, Spain). Moisture content of the herbal material was $7.86 \%$.

\subsection{Chemicals}

Commercial $\mathrm{CO}_{2}$ (purity of $99.9 \%$ w/w) (Messer, Novi Sad, Serbia) was used for laboratory supercritical fluid extraction. All other chemicals were of analytical reagent grade.

\subsection{Hydrodistillation}

The content of essential oil in SW was determined by the Clevenger apparatus following the official method of hydrodistillation prescribed by Ph. Jug. IV (1984).

\subsection{Soxhlet extraction}

Soxhlet extraction of SW was conducted with methylene chloride as a solvent (solid to liquid ratio 1:15 $(\mathrm{g} / \mathrm{mL})$ ). The extractions lasted until the plant material was completely exhausted $(8 \mathrm{~h})$. After the extraction was complete, the solvent was removed from the extract by evaporation on a rotary vacuum evaporator to dryness, and the extraction yield $(\%, \mathrm{w} / \mathrm{w})$ was determined.

\subsection{Supercritical carbon dioxide extraction $\left(\mathrm{SC}-\mathrm{CO}_{2}\right)$}

The laboratory-scale high pressure extraction system (HPEP, NOVA, Swiss, Effertikon, Switzerland) was used for the extraction process. The $\mathrm{SC}-\mathrm{CO}_{2}$ extraction of $\mathrm{SW}$ was conducted at pressures 100, 200, and 300 bar at two temperatures, 40 and $60{ }^{\circ} \mathrm{C}$. Other parameters were kept constant: extraction time $3 \mathrm{~h}$ and $\mathrm{CO}_{2}$ flow rate $0.194 \mathrm{~kg} / \mathrm{h}$. The separator conditions maintained constant at 15 bar and $23^{\circ} \mathrm{C}$.
Table 1. Extraction yield of $\mathrm{SC}-\mathrm{CO}_{2}$ extraction of sweet wormwood

\begin{tabular}{llrr}
\hline $\begin{array}{l}\text { Pressure } \\
{[\text { bar }]}\end{array}$ & $\begin{array}{l}\text { Temperature } \\
{\left[{ }^{\circ} \mathrm{C}\right]}\end{array}$ & $\begin{array}{r}\text { Density } \\
{\left[\mathrm{kg} / \mathrm{m}^{3}\right]}\end{array}$ & $\begin{array}{r}\text { Yield } \\
{[\%]}\end{array}$ \\
\hline 100 & 40 & 628.7 & 2.23 \\
200 & 40 & 839.9 & 3.94 \\
300 & 40 & 910.0 & 5.18 \\
100 & 60 & 290.0 & 2.43 \\
200 & 60 & 723.8 & 3.06 \\
300 & 60 & 830.0 & 3.35 \\
\hline
\end{tabular}

\section{RESULTS AND DISCUSSION}

\subsection{Conventional extraction methods}

The yield of essential oil generally varies between 0.3 and 0.4 $\%$ (v/w) (Holm et al., 1997; Woerdenbag et al., 1993). The hydrodistillation of SW provided an essential oil content of 0.1 $\%$. The volatile components of SW are mainly attributable to essential oils with the content being 0.2-0.25\% (WHO, 2006). Khangholi and Rezaeinodehi (2008) investigated the effect of drying temperature on SW essential oil content and composition. The results demonstrated that higher drying temperatures decreased the essential oil content from $1.12 \%$ at room temperature to $0.50 \%$ and $0.37 \%$ at temperatures $55{ }^{\circ} \mathrm{C}$ and $65^{\circ} \mathrm{C}$, respectively. Using methylene chloride as a solvent in Soxhlet extraction of SW, provided a yield of lipophilic components of $10.28 \%$. The cause of the significant difference in yields achieved by hydrodistillation and Soxhlet extraction lies in the fact that hydrodistillation extracts only volatile compounds, that is essential oil. On the other hand, the Soxhlet extraction with organic solvents extracts not only volatile compounds, but also all other lipophilic compounds such as waxes, pigments, and albuminous materials (Danh et al., 2013). Mohammadian et al. (2016) used methanol as a solvent in Soxhlet extraction of SW aerial parts $(20 \mathrm{~h})$ and obtained a yield of $11.69 \%$. Eteng et al. (2013) subjected SW leaves to Soxhlet extraction at $17-20{ }^{\circ} \mathrm{C}$ for $48 \mathrm{~h}$ using $98 \%$ ethanol and obtained a yield of $14 \%$. Additionally, the Soxhlet extraction of SW leaves with hexane yielded 7.28 \% (Quispe-Condori et al., 2005). The differences in contents could be attributed to the application of different solvents and different geographical origins of the plant, the plant's development stage, climatic conditions, drying and storage methods, and particle size.

\subsection{Influence of process parameters of $\mathrm{SC}-\mathrm{CO}_{2}$ on extrac- tion yield}

SC- $-\mathrm{CO}_{2}$ was applied to obtain SW extracts at 100, 200, and 300 bar and temperatures of 40 and $60{ }^{\circ} \mathrm{C}$, i.e. densities of $\mathrm{CO}_{2}$ in the range $290-910 \mathrm{~kg} / \mathrm{m}^{3}$. After $3 \mathrm{~h}$ of SC-CO $\mathrm{CO}_{2}$ extraction at $40{ }^{\circ} \mathrm{C}$ and different pressures $(100,200$, and 300 bar) extraction yields were in the range $2.23-5.18 \%$ (Table 1 and Figure 1). The lowest yield was obtained at 100 bar, while the application of 300 bar provided a 2.3-fold higher yield. With the increase of pressure at a constant temperature, an increase in the extraction yield was observed, which is in agreement with the statement that with increasing carbon dioxide density, its solvating power also increases (Jerković et al., 2017; Uddin et al., 2015).

Extraction yields obtained at $60{ }^{\circ} \mathrm{C}$ temperature and pressures 100,200 , and 300 bar were in the range 2.43-3.35\% (Table 1 and Figure 2). The lowest yield was obtained at 100 bar, while a 1.4fold higher yield was obtained at 300 bar. By comparing the extraction yields at constant temperature and different pressures, it can be concluded that the highest yield was achieved 


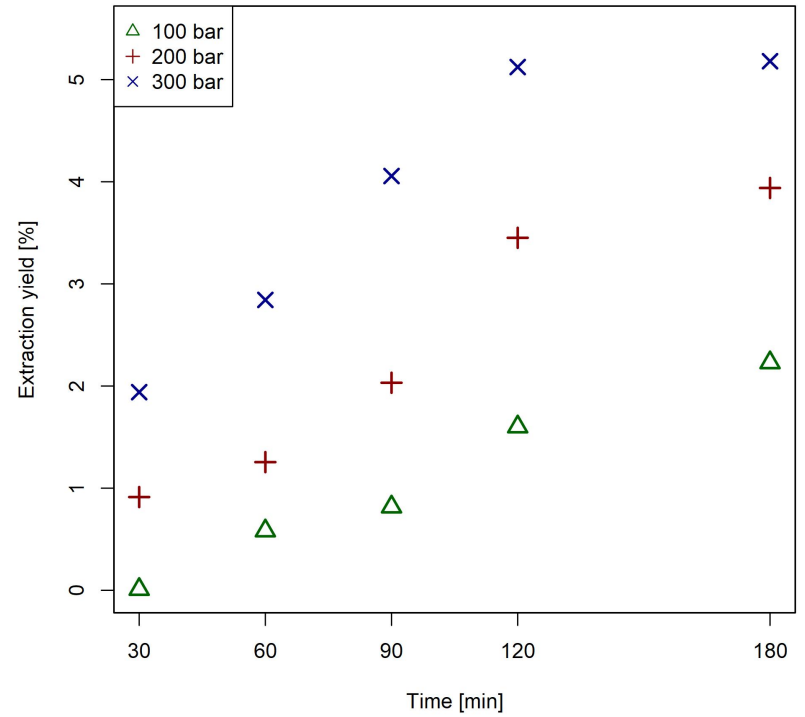

Fig. 1. Extraction kinetics of SC-CO $\mathrm{CO}_{2}$ extraction of sweet wormwood at $100,200,300$ bar and at $40^{\circ} \mathrm{C}$

at 300 bar and $40{ }^{\circ} \mathrm{C}$. This data is important from the economic aspect as well because by using a lower temperature and investing a lower amount of energy compared to the extraction at $60{ }^{\circ} \mathrm{C}$, a higher yield is provided. According to QuispeCondori et al. (2005), maximum artemisinin global yield is achieved at 300 bar and $50{ }^{\circ} \mathrm{C}$ temperature. Li et al. (2017) showed that the extraction time and pressure had the highest positive effect on oil extraction, while the effects of $\mathrm{CO}_{2}$ flow rate and temperature were less important. The extraction yield of $11.17 \%$ was achieved at $250 \mathrm{bar}, 50{ }^{\circ} \mathrm{C}, 25 \mathrm{~g} / \mathrm{min}$, and $2 \mathrm{~h}$ extraction time (Li et al., 2017). However, the range of investigated $\mathrm{CO}_{2}$ flow was $10-30 \mathrm{~g} / \mathrm{min}$, which is a significantly higher $\mathrm{CO}_{2}$ flow than the one applied in this study. Therefore, a significantly higher total yield than the yield obtained in this study could be caused by the higher $\mathrm{CO}_{2}$ flow rate, as well as the difference in particle size.

Considering the yield obtained by the reference Soxhlet method, the SC- $\mathrm{CO}_{2}$ extracted $50.38 \%$ of the lipophilic fraction. Therefore it is necessary to further optimize the SC-CO extraction to obtain higher yields. One approach for obtaining higher yields and better efficiency can be the inclusion of different pretreatments of the raw material such as increasing the moisture of the material, exposing the material to high pressure or ultrasound waves, or adding modifiers (Tzeng et al., 2007; Vidović et al., 2014). Tzeng et al. (2007) showed that $\mathrm{SC}-\mathrm{CO}_{2}$ modified with $2 \mathrm{~h}$ ethanol was superior to $16 \mathrm{~h}$ Soxhlet hexane extractions in producing artemisinin. In addition, the amount of the extracts increased with the increase in the density of SC- $\mathrm{CO}_{2}$.

Kinetics of SC- $\mathrm{CO}_{2}$ of SW delivered two extraction periods, rapid and slow. During the rapid period, components that are easily soluble in $\mathrm{SC}-\mathrm{CO}_{2}$ are extracted. This period is characterized by a coefficient of rapid extraction which represents the amount of material obtained by rapid extraction. This coefficient is directly proportional to the degree of destruction of the plant material used for extraction. In the second extraction period, which is much slower, components with higher boiling points and higher molecular weights, such as fatty oils, waxes, and pigments are extracted. Mass transfer in the slow extraction period is done by slow diffusion (Sovová, 2012).

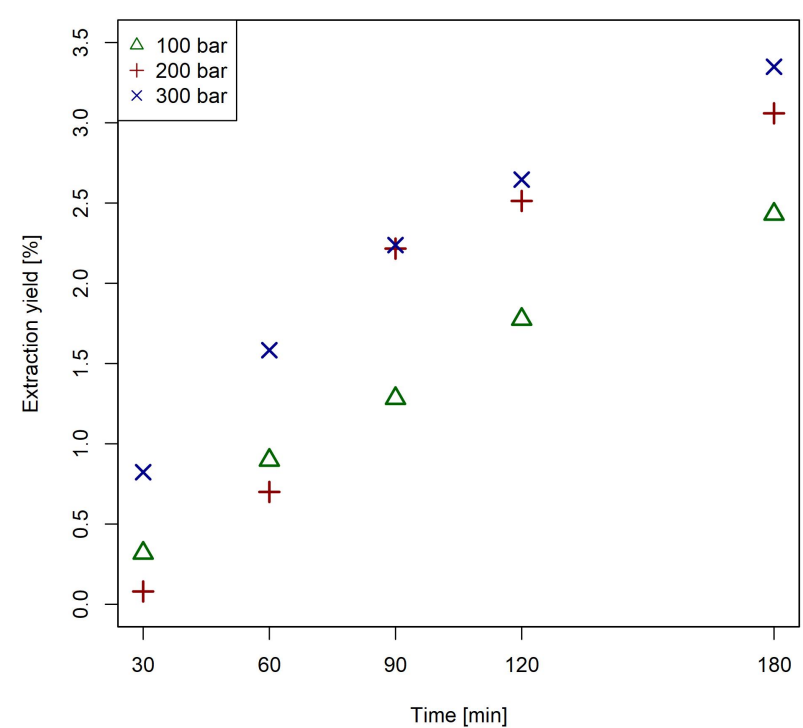

Fig. 2. Extraction kinetics of SC-CO $\mathrm{CO}_{2}$ extraction of sweet wormwood at $100,200,300$ bar and at $60^{\circ} \mathrm{C}$

\section{CONCLUSION}

Increasing environmental awareness of the concept of green production processes has imposed the need to implement environmentally friendly innovative processes in production plants. Therefore, $\mathrm{SC}-\mathrm{CO}_{2}$ can be classified as a promising alternative technology, which provides a quality product, with full integration into the concept of clean and environmentally friendly processes, thus overcoming one of the main disadvantages of this technology - high investment costs. The achieved results of this study demonstrate that $\mathrm{SC}-\mathrm{CO}_{2}$ did not result in the complete exploitation of the raw material and maximal extraction of lipophilic compounds. The referential Soxhlet method of extraction achieved an approximately two times higher yield. Therefore, further investigation is necessary to exploit the material more efficiently, as well as the chemical analysis of the obtained extracts.

\section{ACKNOWLEDGMENTS}

This research was funded by Ministry of Education, Science and Technological Development of the Republic of Serbia; Project No. 451-03-68/2020-14/200134.

\section{REFERENCES}

Bhakuni, R. S., Jain, D. C., Sharma, R. P., Jain, D. C. and Sharma, R. P. (2002). Phytochemistry of Artemisia annua and the development of artemisinin-derived antimalarial agents, in C. Wright (ed.), Artemisia, Taylor and Francis, London.

Danh, L. T., Han, L. N., Triet, N. D. A., Zhao, J., Mammucari, R. and Foster, N. (2013). Comparison of chemical composition, antioxidant and antimicrobial activity of lavender (Lavandula angustifolia L.) essential oils extracted by supercritical $\mathrm{CO}_{2}$, hexane and hydrodistillation, Food and Bioprocess Technology 6(12): 3481-3489.

Efferth, T., Dunstan, H., Sauerbrey, A., Miyachi, H. and Chitambar, C. (2001). The anti-malarial artesunate is also active against cancer, International Journal of Oncology 18(4): 767773.

Eteng, M. U., Abolaji, A. O., Ebong, P. E., Brisibe, E. A., Dar, A., Kabir, N. and Iqbal Choudhary, M. (2013). Biochemical 
and haematological evaluation of repeated dose exposure of male wistar rats to an ethanolic extract of Artemisia annua: Safety assessment study on Artemisia annua, Phytotherapy Research 27(4): 602-609.

Ferreira, J. F. S., Simon, J. E. and Janick, J. (1997). Artemisia annua: Botany, horticulture, pharmacology, in J. Janick (ed.), Horticultural Reviews, Vol. 19, John Wiley \& Sons, Ltd, chapter 6, pp. 319-371.

Graziose, R., Ann Lila, M. and Raskin, I. (2010). Merging traditional Chinese medicine with modern drug discovery technologies to find novel drugs and functional foods, Current Drug Discovery Technologies 7(1): 2-12.

Haghighian, F., Sendi, J. J., Aliakbar, A. and Javaherdashti, M. (2008). The growth regulatory, deterrency and ovicidal activity of worm wood (Artemisia annua L.) on Tribolium confusum Duv., Pestycydy 1-2: 51-59.

Hasheminia, S. M., Sendi, J. J., Jahromi, K. T. and Moharramipour, S. (2011). The effects of Artemisia annua L. and Achillea millefolium L. crude leaf extracts on the toxicity, development, feeding efficiency and chemical activities of small cabbage Pieris rapae L. (Lepidoptera: Pieridae), Pesticide Biochemistry and Physiology 99(3): 244-249.

Holm, Y., Laakso, I., Hiltunen, R. and Galambosi, B. (1997). Variation in the essential oil composition of Artemisia annua L. of different origin cultivated in Finland, Flavour and Fragrance Journal 12(4): 241-246.

Hsu, E. (2006). The history of qing hao in the Chinese materia medica, Transactions of the Royal Society of Tropical Medicine and Hygiene 100(6): 505-508.

Jerković, I., Molnar, M., Vidović, S., Vladić, J. and Jokić, S. (2017). Supercritical CO 2 extraction of Lavandula angustifolia Mill. flowers: Optimisation of oxygenated monoterpenes, coumarin and herniarin content, Phytochemical Analysis 28(6): $558-566$

Khangholi, S. and Rezaeinodehi, A. (2008). Effect of drying temperature on essential oil content and composition of sweet wormwood (Artemisia annua) growing wild in Iran, Pakistan Journal of Biological Sciences 11(6): 934-937.

Khosravi, R., Sendi, J. and Ghadamyari, M. (2010). Effect of Artemisia annua L. on deterrence and nutritional efficiency of lesser mulberry pyralid (Glyphodes pylolais Walker) (Lepidoptera: Pyralidae), Journal of Plant Protection Research 50(4): 423-428.

Lapkin, A. A., Plucinski, P. K. and Cutler, M. (2006). Comparative assessment of technologies for extraction of artemisinin, Journal of Natural Products 69(11): 1653-1664.

Laughlin, J., Heazlewood, G. and Beattie, B. (2002). Cultivation of artemisia (Artemisia annua Linn.), in C. Wright (ed.), Artemisia, Taylor and Francis, London.

Li, Y., Xia, L., Vazquez, J. F. T. and Song, S. (2017). Optimization of supercritical $\mathrm{CO}_{2}$ extraction of essential oil from Artemisia annua L. by means of response surface methodology, Journal of Essential Oil Bearing Plants 20(2): 314-327.

Mohammadian, A., Moradkhani, S., Ataei, S., Shayesteh, T. H., Sedaghat, M., Kheiripour, N. and Ranjbar, A. (2016). Antioxidative and hepatoprotective effects of hydroalcoholic extract of Artemisia absinthium L. in rat, Journal of Herbmed Pharmacology 5(1): 29-32.
Moore, J. C., Lai, H., Li, J.-R., Ren, R.-L., McDougall, J. A., Singh, N. P. and Chou, C.-K. (1995). Oral administration of dihydroartemisinin and ferrous sulfate retarded implanted fibrosarcoma growth in the rat, Cancer Letters 98(1): 83-87.

Nađalin, V., Lepojević, i., Ristić, M., Vladić, J., Nikolovski, B. and Adamović, D. (2014). Investigation of cultivated lavender (Lavandula officinalis L.) extraction and its extracts, Chemical Industry and Chemical Engineering Quarterly 20(1): 71-86.

Ph. Jug. IV (1984). Pharmacopoea Jugoslavica, $4^{\text {th }}$ edn, Federal Institute of Public Health, Belgrade, Yugoslavia.

Quispe-Condori, S., Sánchez, D., Foglio, M. A., Rosa, P. T., Zetzl, C., Brunner, G. and Meireles, M. A. A. (2005). Global yield isotherms and kinetic of artemisinin extraction from Artemisia annua L leaves using supercritical carbon dioxide, The Journal of Supercritical Fluids 36(1): 40-48.

Sahena, F., Zaidul, I., Jinap, S., Karim, A., Abbas, K., Norulaini, N. and Omar, A. (2009). Application of supercritical $\mathrm{CO}_{2}$ in lipid extraction - A review, Journal of Food Engineering 95(2): 240-253.

Shekari, M., Sendi, J. J., Etebari, K., Zibaee, A. and Shadparvar, A. (2008). Effects of Artemisia annua L. (Asteraceae) on nutritional physiology and enzyme activities of elm leaf beetle, Xanthogaleruca luteola Mull. (Coleoptera: Chrysomellidae), Pesticide Biochemistry and Physiology 91(1): 66-74.

Singh, N. P. and Lai, H. (2001). Selective toxicity of dihydroartemisinin and holotransferrin toward human breast cancer cells, Life Sciences 70(1): 49-56.

Sovová, H. (2012). Steps of supercritical fluid extraction of natural products and their characteristic times, The Journal of Supercritical Fluids 66: 73-79.

Tan, R., Zheng, W. and Tang, H. (1998). Biologically active substances from the genus Artemisia, Planta Medica 64(04): 295302.

Tzeng, T., Lin, Y., Jong, T. and Chang, C. (2007). Ethanol modified supercritical fluids extraction of scopoletin and artemisinin from Artemisia annua L., Separation and Purification Technology 56(1): 18-24.

Uddin, M. S., Sarker, M. Z. I., Ferdosh, S., Akanda, M. J. H., Easmin, M. S., Bt Shamsudin, S. H. and Yunus, K. B. (2015). Phytosterols and their extraction from various plant matrices using supercritical carbon dioxide: a review, Journal of the Science of Food and Agriculture 95(7): 1385-1394.

Vidović, S., Zeković, Z., Marošanović, B., Todorović, M. P. and Vladić, J. (2014). Influence of pre-treatments on yield, chemical composition and antioxidant activity of Satureja montana extracts obtained by supercritical carbon dioxide, The Journal of Supercritical Fluids 95: 468-473.

Vladić, J., Zeković, Z., Jokić, S., Svilović, S., Kovačević, S. and Vidović, S. (2016). Winter savory: Supercritical carbon dioxide extraction and mathematical modeling of extraction process, The Journal of Supercritical Fluids 117: 89-97.

Watson, L. E., Bates, P. L., Evans, T. M., Unwin, M. M. and Estes, J. R. (2002). Molecular phylogeny of subtribe artemisiinae (Asteraceae), including Artemisia and its allied and segregate genera, BMC Evolutionary Biology 2(1): 17.

WHO (2006). WHO monograph on good agricultural and collection practices (GACP) for Artemisia annua L., WHO Press, Geneva, Switzerland. 
Woerdenbag, H. J., Bos, R., Salomons, M. C., Hendriks, H., Pras, N. and Malingré, T. M. (1993). Volatile constituents of Artemisia annua L. (Asteraceae), Flavour and Fragrance Journal 8(3): 131-137.

Wright, C. W. (2005). Traditional antimalarials and the development of novel antimalarial drugs, Journal of Ethnopharmacology 100(1-2): 67-71. 